\title{
Locating Bengaluru as India's Silicon Valley
}

\author{
Suparna Majumdar Kar*
}

\begin{abstract}
Bengaluru is one of the fastest growing cities in India. This paper traces the emergence of Bengaluru as one of the leading hubs of Information and Communication Technology as well as Research and Development in India. This is rooted in a complex combination of historical forces such as leadership during the colonial and post-independence periods, the influence of the city's colonial past, infrastructure development, as well as the impact of policy, and shifts in the same in independent India. Some of the more recent forces that have helped to shape the city have been the investment in educational and research institutions of high repute as well as in Public Sector Undertakings which resulted in the unique character of the city and its culture. These, along with a favourable policy climate, have been influential in the emergence of the city as a global leader in the field of Research and Development and Information Technology which has earned it its nickname of the 'Silicon Valley of India'.
\end{abstract}

Keywords: Bengaluru, Information Technology, Silicon Valley.

\section{Introduction}

Bengaluru, the capital of Karnataka in South India, has emerged as a hub for organizations working with Information and

* Department of Sociology, Christ University, Bengaluru, India; suparna.kar@christuniversity.in 
Communication Technology or IT and ICT. It has been widely described as the 'Silicon Valley of India', the 'Silicon Plateau' as well as the 'IT City of India'. Newspaper reports (The Hindu, 2010; DNA, 2011) have been referring to Bengaluru as the Silicon Valley of India since the late 1980's. This nomenclature has been widely reflected within academia, as well as in popular understandings over the years (Heitzman, 1999, 2001; Mascarenhas, 2012; Parthasarathy, 2004; Patni, 1999; Saxenian, 2000; Stremlau, 1996). Today, the city is also gaining the title of the start-up city or the 'start-up capital' of India (India IT-BPM Overview, 2016; Venkat, 2015).

Bengaluru is called India's Silicon Valley with reference to the original Silicon Valley in California, USA, which has been one of the world's oldest major hubs in Information Technology. This allusion to Bengaluru as the Silicon Valley is a reference to its significant position in the field of IT and ICT, as well as its longstanding association with science and technology, and research and development. This paper traces the emergence of Bengaluru as a hub for IT and its evolution into India's Silicon Valley with special emphasis on the forces that contributed to this process.

\section{Brief History of the city}

What we currently known as Bengaluru was established in the sixteenth century even though some of the earliest archaeological references to the city date back to the ninth century. The foundations for the current city were laid by Magadi Kempe Gowda who built a mud brick fort around what is central Bengaluru today in 1537. This fort covered the pete area in the city, today's Chickpet and the surrounding market area. Since then, the city has been controlled by the Mughals, Wodeyars and then Hyder Ali and Tipu Sultan, following which the British set up a Cantonment in the early nineteenth century. Bengaluru, has evolved in tune with these historical shifts. The pre independence city had a dual character centred around the pete area and the British Cantonment.

The city has grown rapidly since its inception and is home to over 10 million people. It is one of the fastest growing urban areas in 
India today. Figure 1 shows the magnitude of the increase of the population from 1941 to 2016. The data for 1941 through to 2011 has been derived from the Census of India, while the population for 2016 is based on a projection provided by the Directorate of Economics and Statistics in 2013. This increase has been an outcome of a combination of reclassification as well as population growth due to natural increase and migration.

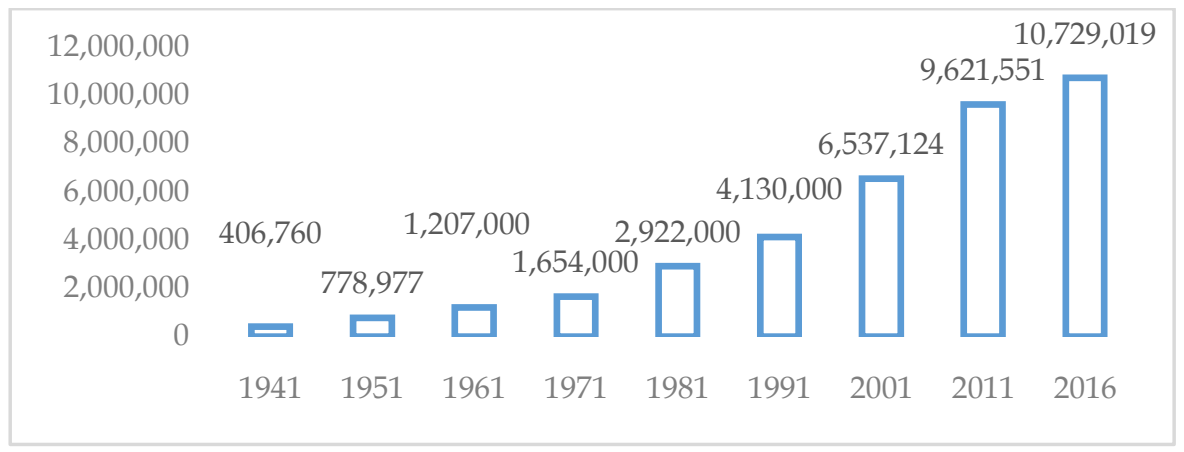

Fig1: Bengaluru: Population growth

The density of population in the city has also increased by $47 \%$ to 4,378 people/square kilometre over the past decade. This increase has been manifold from the population density of 421 in 1971 to the 4, 378 in 2011(Census of India, 2015). According to the Director of Census Operations, Karnataka, "One in every six persons in Karnataka lives in Bengaluru." According to the same source, Bengaluru has proven itself to be a very attractive destination due to the economic growth that it has enjoyed.

\section{IT in Bengaluru}

The IT sector plays a significant role in the economy of the state in general and the city in particular. $21.4 \%$ of the Gross State Domestic Product of Karnataka is derived from the export of software. The KIG 2020 report (2012, p. 5)states that $44.6 \%$ of all investments made in the IT industry in India during 2010-11 was in Karnataka. The state also houses 'a third of the software companies contributing more than $35 \%$ of the national exports'. $80 \%$ of the world's global IT companies have centres in Bengaluru, including setting up their Research and Development centres. The city is 
ranked fourth in terms of being a global technology cluster closely following Silicon Valley, Boston and London. Bengaluru has more than 2100 IT companies and is host to almost a third of India's software parks (Advantage Karnataka, 2014). The city was also the first Indian city to feature on the 'City Momentum Index' at 12 out of 20 of the top technology rich cities across the world (Kelly et al.,2016).

There were 2239 Software Technology Parks (STP) in 2012-13 and 69 Electronic Hardware Technology Parks (EHTP) in Bengaluru in 2012-13. There are 845 member units in these STPs in the city. Bengaluru has emerged as a hub for IT in India and this is reflected in how it attracts personnel working in that industry. In fact, a study done by the Aspiring Minds Research Cell in 2011 placed Bengaluru first among the cities preferred by IT Engineers for their first jobs. The Department of Information Technology, Biotechnology and Science and Technology (2011), Government of Karnataka, calls Bengaluru the 'IT Capital of India'.

The report of the City Momentum Index, 2016, states that Bengaluru'...is effectively the 'Silicon Valley of India". The report attributes this to the "mix of research institutes and higher education establishments helping to create a solid and sizeable IT cluster.' According to them $40 \%$ of India's IT industry is located in the city. They also state that the city's entrepreneurial growth can be attributed to the presence of international IT giants which is boosted by the highest concentration of high tech start-ups (Kelly et al., 2016, p.7). Nine out of the top ten IT companies listed by Forbes Global 2000 list have also headquartered their operations in India in Bengaluru, consolidating its significance in the sector.

It thus becomes important to examine the factors that have contributed to this. Why did Bengaluru emerge as the leader in the IT sector and not cities like Mysuru or Chennai? What were the historical forces that contributed to this? Social capital, adequate human resources, a conducive, natural, physical and social environment, supportive policies, infrastructure and responsive governance are some of the factors that are considered to be important for the development of the IT sector. This paper now examines some of the factors that facilitated these changes in this region. 


\section{Facilitating Factors}

Historical Factors. Historically, Bengaluru was governed by progressive leaders. Interventions by Hyder Ali and Tipu Sultan helped the city to gain the label or the 'Garden City' of India as they established Lalbagh, the botanical gardens, which act as a lung space for the city. The leaders under the Wodeyars as well as those that followed were equally progressive and focused on the industrialization and the development of quality education in the region. As Gowda (2010) puts it, the elites in the State of Mysore looked at industrialization as development during the nineteenth century and this was reflected in the implementation of projects on hydroelectric energy, irrigation as well as industries such as the Bhadravati Iron Works.

Colonial intervention also resulted in the development of infrastructure in the city. Bengaluru had the distinction of being one of the first cities to benefit from the trappings of modernity in India. Some of these were the introduction of the telegraph in 1853, railways in 1854, telephone in 1898, and then by air in 1940. It was also one of the first cities to be electrified in 1906 as it used hydroelectric power under the Cauvery Power Scheme. The excess power that was not being used by the Kolar Gold Fields, the original intended beneficiary of the scheme, was used to electrify the city. The then Maharaja of Mysore, Krishnaraja Wodeyar, believed that this would also encourage the establishment of industry in the city.

The vision of Bharat Ratna M Visvesvaraya (1860-1962), the Dewan of Mysore from 1912-1918, widely known as the 'Father of the modern Mysore state', was also instrumental in shaping the region. He was a renowned engineer and scholar whose motto was to 'industrialize or perish'. Visvesvaraya's contributions have had an impact on the entire region and have played a very significant role in its evolution. He believed that a population that was educated and equipped with a necessary set of skills was important in laying the foundations for development. This focus on education and the acquisition of skills was reflected in his lifelong work. He also contributed immensely to the development of industry in the state in areas like sericulture as well as the setting up of industries like 
the Mysore Soap Factory, and the Mysore Iron and Steel Works (Vyasulu, 1989).

As mentioned earlier, the British had played a significant role in the evolution of Bengaluru. The plague epidemic of 1898 resulted in shifting focus to health and sanitation. This had an impact on the layout of the city as housing plans were made keeping sanitation in mind and the Victoria hospital was established in 1900. This also resulted in the setting up of telephone lines to facilitate coordination of health care workers during the plague outbreak, across the city. These changes in the layout as well as the physical infrastructure of the city laid the foundations for the modern city of Bengaluru. This in conjunction with the other initiatives taken to enhance both the infrastructure as well as connectivity were important. These initiatives reflected a focus on the development of infrastructure which had a lasting impact on the future of the city.

Education: Stremlau (1996) emphasised the role played by both the British colonizers in terms of their contribution to the legal framework and their focus on English as a medium of communication as well as the post-Independence Nehruvian interventions. This emphasis on education was important and the city benefitted from a focus on quality education. Karnataka is home to more than 12 universities and over a thousand general, medical and engineering colleges. Bengaluru is host to some of the most prestigious educational institutions and research institutes such as the Indian Institute of Management, Bangalore (IIM-B), Indian Institute of Science (IISC), Indian Institute of Information Technology, Bangalore (IIT-B), Institute of Bioinformatics and Applied Biotechnology, Bangalore (IBAB), Defence Research \& Development Organisation (DRDO), ISRO Satellite Centre (ISRO), Indian Institute of Astrophysics and the Raman Research Institute.

Visvesvarya held that education and the attainment of vocational skills as well as technological education would be a means for the development and advancement of the region. The School of Engineering established by him in 1862 was followed by 23 additional schools across the state. He was also instrumental in the establishment of the Government Engineering College in Bengaluru in 1917 which was the first engineering college in the state. Other prominent schools in Bengaluru were established in the 
nineteenth century. The Baldwin Boys High School was founded in 1800, St Joseph's Boys High School in 1858 and Bishop Cottons Boys School in 1880. This history of formal education often with English as the primary medium of instruction reflects the emphasis placed on the same.

Another institution that was established to further research and teaching in the field of science was the Indian Institute of Science (IISc) which was established in 1909. The first batch of 20 students joined in 1911. This initiative was spearheaded by the efforts of its founder, Jamsetji Tata with support from Krishnaraja Wodeyar, the Maharaja of Mysore and the Government of India. This Institute was instrumental in establishing Bengaluru's reputation of being a hub for scientific research and development. IISC is one of the highest rated institutions for scientific research and has been the home for highly acclaimed faculty and alumni (IISC, 2015). Luminaries of science like C V Raman and C N R Rao have officiated as Directors of the Institute. Visvesvaraya, HomiBhaba and Vikram Sarabhai have been Honorary Fellows at the Institute. The institute has also produced alumni who are leaders in research and development in science and technology.

Bengaluru is also home to a number of prestigious and highly acclaimed private Universities and Institutes of Technology like the International Institute of Information Technology (IIIT), M. S. Ramaiah Institute of Technology (MSRIT) and the Rashtreeya Vidyalaya College of Engineering (RVCE). The state too ,has many highly acclaimed Technological Colleges such as the National Institute of Technology (NIT), Surathkal, and the Sri Jayachamarajendra College of Engineering, Mysore (SJCE).

These educational institutions along with other research institutes in the city and across the state reflected the focus on quality education as well as research and development. This has been bolstered by numerous highly acclaimed schools which have emphasised quality primary education and laid the foundation for effective optimization of higher education. These have contributed towards producing the human capital that was necessary for the city to emerge as the IT capital or the Silicon valley of India. 
In Independent India, Nehru defined the path to be taken over the next few decades. India had to deal with a faltering economy which needed a boost. In the years following Independence, development in Bengaluru was marked by the Nehruvian philosophy of state directed industrialization. Import substitution was adopted as an initiative which laid emphasis on the development of Indian Science and Technology. This focus on import substitution necessitated the establishment of a robust public sector and investment in research in science and technology which in turn would guide industry.

Significance of PSUs and Industry: India invested in Public Sector Undertakings (PSU) to lead the way towards self-sufficiency guided by the ideals of socialism. The first Public Sector Undertaking in the country was the Indian Telephone Industry that was established in Bengaluru in 1948. This Nehruvian model of import substitution lasted till the 1990s when it was challenged by the processes of liberalization, globalization, and privatization. By the time liberalization was ushered in in the early part of the 1990s, India had 244 Public Sector Undertakings, many of which were operating from Bengaluru. Nehru considered Bengaluru to be the 'City of the Future' and this was aided by the investments made in the 1940s and 50s in the newly independent country. As already stated, Bengaluru was home to many Public Sector Undertakings. A number of these were associated with the Ministry of Defence, Ministry of Commerce, the Council of Scientific and Industrial Research under the aegis of the Government of India. This investment also helped in consolidating the city's reputation as a leader in the realm of science and technology.

Bengaluru was also a vibrant industrial hub. It has had a concentration of both Central and State Public Sector Undertakings which has been reflected in the employment in these units. A study on employment and structural changes in the Indian industry reiterates the same. A study from the 1980s reflects how the PSUs attracted employees from all across the country. (ILO-ARTEP, 1989) These factors contributed to the cosmopolitan character of the workforce and their influence on the nature of the city. Hindustan Aircraft was set up in 1940 and later renamed Hindustan Aeronautics Limited (HAL) in 1964. HAL was established with the 
intention of establishing a foothold in aeronautics by setting up units to manufacture aircraft in India. It has been instrumental in the conceptualization, design and manufacture of aircraft like the Light Combat Aircraft and the Chetak helicopters. (HAL, 2015)Today HAL is one of the largest aerospace companies in Asia with a prominent international presence. With more than 32,000 employees, it too has a workforce from across the nation.

Indian Telephone Industries (ITI) was established in 1948 to manufacture components for the Department of Telecommunications. It was India's first Public Sector Undertaking which started with two plants, both of which were based in Bengaluru till 1973 when it set up units in other cities in the country. Their Headquarters and Research and Development unit continue to be located in Bengaluru (Heitzman, 1999; ITI Limited, 2016).

Hindustan Machine Tools (HMT) was established in 1953 as a unit to manufacture machine tools. It later diversified its activities and engaged in the manufacture of watches and tractors. It also manufactured die casting and plastic processing machinery. HMT too has focused on active Research and Design to enable and guide its manufacturing units(HMT, 2015). In a sign of the changing times, the HMT watch factory shut down in April 2016. This marked the end of an era which had been dominated by the PSUs.

Bharat Electronics Limited (BEL) was founded in 1954 under the Ministry of Defence to cater to the electronic needs of the Indian Defence Services. Since its inception it has kept up with the global advances in technology. BEL currently houses nine Strategic Business Units in Bengaluru (BEL, 2015). National Aerospace Laboratories (NAL) is another unit that moved its Headquarters to the city in 1960, a year after its establishment in 1959. NAL is a constituent of the Council of Scientific and Industrial Research. NAL is described as India's 'premier' Research and Development unit working in the field of aeronautics and its allied units (NAL, 2015).

Bharat Earth Movers Limited (BEML) was established in 1964 and it engages primarily with Defence and Aerospace, Mining and Construction and Railways and Metro. The Bengaluru centre works 
primarily on production related to rail and metro and also on mining equipment(BEML, 2015). Central Manufacturing Technology Institute (CMTI) and Bharat Heavy Electricals Limited (BHEL) also have their operations in Bengaluru. BHEL, which works on industrial engineering and manufacturing, was established in 1964 with its headquarters in Delhi. It has three of its units in Bengaluru, namely the Electronics Division, Industrial Systems Group and Electro-Porcelains Division. The Electronics Division in Bengaluru houses two of its Centres of Excellence in terms of Research and Design. It has also constituted the Ceramic Technological Institute in the city (BHEL, 2015).

The Indian Space Research Organization (ISRO) was established in 1969 with its headquarters in Bengaluru. ISRO has worked extensively on the design and development of space technology. It has 11 centres in Bengaluru including its Headquarters which shares with the Department of Space, Government of India. It is also home to the Space Commission which works on policy formulation and implementation for the Indian Space Program. (ISRO, 2015) They have successfully worked on satellites, satellite launchers and the recent Mars Mission.

The fact that most of these public sector undertakings were headquartered in the city, reinforced Bengaluru's reputation and made it a centre for scientific research and development that attracted personnel working in these sectors associated with scientific research and development in the sector related to air and space, telecom and electronics technology. As Stremlaustates, '...India's central government invested heavily in building Bengaluru's civilian science and technology infrastructure as well as the nation's most advanced military and space research facilities.' (Stremlau, 1996, p. 50). These Public Sector Undertakings established by both the Central and the State Governments, helped shape the culture of the city. The employees of these PSUs contributed immensely to the character of the city. They emphasised the development of human capital which was utilized upon the advent of the era of liberalization, privatization and globalization.

Bengaluru also had a formidable reputation of being an industrial centre. A number of private companies also set up in the city. Binny 
and Co had set up the highly successful Bengaluru Cotton, Silk and Woollen Mills in 1884. This was a forerunner to the city operating as a hub for textiles and the garment industry which continues till date. Karnataka Soaps and Detergents Ltd established the Government Soap Factory that was instrumental for the introduction of the now famous Mysore Sandal Soap in 1918. Bosch is another company that set up its manufacturing plant in Bengaluru in 1954 and made the Motor Industries Company Limited, or MICO Bosch, a centre for its automotive production activities.

We thus see that the evolution of Bengaluru and its emergence as India's Silicon Valley has been aided by the historical shifts that the city has gone through. Some of the important factors that have contributed to this have been the attitude of the leaders, their focus on the development of infrastructure, the development of scientific education and formal education which helped nurture this scientific temper. The development of infrastructure, such as the telephone, railways and air transport, which have helped connect Bengaluru with the rest of the nation and the world also helped. All this was aided by the shifts brought about in independent India with the establishment of PSUs in the city, many of which focused on science and technology.

Nair's work (2005), though primarily from the realm of urban studies, also points out that the transitions that Bengaluru has gone through can be traced through three stages, the first two of which are marked by the dominance of the textile industry and the public sector undertakings in the city. The third stage was marked by the advent of IT.The advent of IT has been aided by all the factors that have already been discussed as they helped to create a conducive environment as well as provide an able, well trained workforce. In addition, the progressive policies adopted by the State also aided this process.

IT Policy and a Conducive Climate.Heitzman (1999) notes that Bengaluru's reputation of being the 'Silicon Valley' of India dates back to the mid-1980s with the establishment of the first Software Technology Parks or STPs in the city. This was aided by the era of liberalization ushered in by the then Rajiv Gandhi government which brought along with it numerous interventions and 
innovations in the fields of electronics and technology. The Government of Karnataka established Karnataka State Electronics Development Corporation Limited (KEONICS) in 1976 under the guidance of the then Chief Minister D. Devaraj Urs. KEONICS was envisaged as a body that would enhance the establishment of electronics industries in the state by building infrastructure and creating a conducive environment. $\mathrm{R} K$ Baliga, was the first Chairman and Managing Director of KEONICS. He was instrumental in the establishment of Electronic City which was home to some of the first Software Technology Parks in India in the 1980s(Karnataka State Electronics Development Corporation Limited, 2015).

Texas Instruments was the first prominent Multi National Corporation to set up in Bengaluru as a result to these shifts. Texas Instruments started out in the city with their Research and Development unit in 1986 with a total staff of 33 of which 26 were engineers. Their revenues were US\$ 0.5 million at that time. As Texas Instruments (2016) put it, India has been a source of 'great talent, great leadership and great innovation'.

The Centre for Development of Telematics (C-DOT) was established in 1984 in order to develop technology for the telecommunication industry. The state of the art facility was projected as a centre for excellence in the field. The Centre for Development of Advanced Computing (C-DAC) was established in 1988. The Department of Electronics and Information Technology (DeitY), under the Ministry of Communications \& Information Technology (MCIT) established C-DAC as its institute for Research and Development in the fields of Information Technology and Electronics. One of its early undertakings was the building of a supercomputer. The fact that both C-DOT and C-DAC had centres in Bengaluru aided the development of its image as a forerunner in research and development in cutting edge technology.

Stremlau (1996)has written about the significant role played by the software sector in Bengaluru on a global scale in spite of some the infrastructure hurdles and stark inequality in the country. Organizations like General Electric, IBM, and Texas Instruments depended on Institutions working out of Bengaluru for their computer software needs. In a reinforcement of the quality of the 
work being done in the city, Carnegie Mellon's Capability Maturity Model rated the teams operating out of the city very highly. The 1990s saw a shift from the export of human resources like software programmers towards an export of finished products like software programmes making the city a major player in the software industry rather than being just a body shopping haven.

In a progressive move, the Government of Karnataka was the first state to announce a 'Package of Incentives and Concessions for New Industrial Investments in Karnataka 1993-1998' followed by its IT Policy in 1997. The aim was to work toward the eradication of poverty and the empowerment of women by using the power of IT to generate employment and adopt e-governance. Also included were emphases on providing an environment of incubation and incentives to IT companies.

An outcome of the IT Policy undertaken by the Government of Karnataka in 1997 was the establishment of the International Institute of Information Technology in the city of Bengaluru in 1999. This Institute is also known as IIIT-B and became a deemed university in 2005 . The primary objective behind the establishment of the institute was to train engineers for the software industry which in turn would help to strengthen Bengaluru's position as a leader in the IT industry. The institute also engaged in the important activities of research and development, dissemination of knowledge and setting standards (Viswanathan, 1998). The success of this institute can be measured in terms of the 1300 plus postgraduates and research scholars working with the leaders in the industry today (IIIT-B, 2015).

These reflect the status of Bengaluru as a city that has been a hub for industry and technology, education and development. It is reinforced by the fact that Karnataka was the first state in the country to implement an IT policy. Bengaluru today is home to many IT companies with Electronic City alone housing more than 120. Bengaluru today also houses more than 80 multinational corporations working in software development (Mascarenhas, 2012 , p. 240). In addition to setting up their software development in the city, many organizations have made the city their home for research and development. Some of the organizations that have done that are Airbus, Bosch, GE, GM, Google, Microsoft, Nokia, 
Philips, Shell and Toyota. This reinforces the cities significance in terms of both IT as well as Research and Development.

Patni (1999) wrote about the emergence of Bengaluru as the 'technological capital of India' and its transformation from the 'quiet summer retreat' of the Raj. Patni identified English speaking skilled workers, a supportive government, relaxed atmosphere and relatively low wages as the driving forces behind this transformation. Heitzman $(1999 ;$ 2001) looked at the city's association with the software industry as well as its focus on technology, research and industry. Cities like Bengaluru act as centres for technological innovation which drive the economy and also define directions of migration. This can be studied in terms of 'milieux of innovation' as evolved in the work by Castells and Hall. Heitzman(2003, p. 57)described the city as a 'technopole' or a 'growth pole' and states that Bengaluru emerged as the 'Silicon Valley' as long back at the mid-1980s with economic liberalization and the establishment of software technology parks.

According to a listing by the Software Engineering Institute (SEI) at Carnegie Mellon University, USA, and the Capability Maturity Model (CMM) developed by them, approximately half of the world's level five certified companies are present in Bengaluru along with a significant portion of the leading IT companies of the world, including Infosys, Wipro, Tata Consultancy Services, Oracle, Dell, IBM, Microsoft, Accenture, and Cognizant. NASSCOM's ranking of the top 20 IT service companies also lists out companies which have a significant presence in the city. This has been accompanied by a concentration of some of the best minds working in the industry which in turn has helped to attract more human resources and has contributed to the successes experienced by the industry.

\section{Conclusion}

Bengaluru is, thus, widely known today as the Silicon Valley of India as this term alludes to its dominant position in the field of IT. This is reinforced by the presence of a significant number of globally prominent organizations as well as their work force who have engaged with IT processes as well as Research and 
Development. Some of the significant factors that have helped Bengaluru to consolidate its position as a leader in the field of Information Technology include its early advantage in terms of its prominence in the field of science and technology with a focus on research and development. This took place due to several reasons such as the encouragement by the various local, regional and national leaders and administrators dating back to the pre-colonial period, who have been at the helm of the city and the broader region. Many of them have emphasised development and the growth of infrastructure along with investment in quality education.

Basic infrastructure within the city along with its connectivity with the rest of the world through the telecom networks as well as its physical connectivity in terms of rail networks and air transport have helped. Other aspects of infrastructure which aided this process have been the early availability of electricity, sanitation facilities and good health care. These have made the city an attractive option for the population that was required for the evolution of the field of IT in the region. The fact that Bengaluru was one of the first cities in the region to benefit from these advances, clubbed with the human resources available, helped it to later consolidate its position of dominance in the emerging field of IT.

Its focus on quality education, research and development have therefore been vital to this process. This was reflected in the establishment of the various schools and institutions of higher education and research and development, especially in the fields of science and technology. The establishment of numerous public sector undertakings, many of which were associated with the fields of science and technology, have made the city a centre for technological advancement and also given it its cosmopolitan character. PSUs like HAL, BEL and ISRO have contributed towards this. The focus on quality primary and higher education, engagement with research and development in the fields of science and technology, long association with PSUs created a conducive environment for the nurture of human resources and the necessary social capital that were optimized the IT sector. 
Bengaluru's geographical location has been important aswell. The fact that it is centrally located within the nation as well as its comfortable and salubrious climate have made it an attractive destination for many. So has been the investment in physical infrastructure which has been accompanied by the setting up of companies working in the IT sector in the region. This geographical location has also enabled companies established in different time zones to set up in the city in order to ensure seamless work throughout the day as the workers here could take up from where those in different time zones left off. This was part of the business process outsourcing initiatives which were a significant part of the IT sector in India.

All these factors have helped the city emerge as a leader in the field of IT in the region as well as globally. This has helped Bengaluru to consolidate its position as the Silicon Valley of India. This has, in turn, brought about numerous shifts which have altered the very fabric of the city by changing its composition, culture and lifestyle as well as the natural environment within which it exists.

\section{Reference}

Advantage Karnataka. (2014, September 5). Retrieved from Advantage Karnataka: http://www.advantagekarnataka.com/ investment-sector/it.php\#.VBxtB5SSz6g

Ahmad, Z. (2010, August 19). US 'reverse brain drain' to India now in full swing. Retrieved March 24, 2011, from BBC News : http://www.bbc.co.uk/news/world-south-asia-10614936

Akbar, A. (2004, August 2). India looks to 'brain gain' as new affluence draws migrants back in their thousands. Retrieved March 24, 2011, from The Independent: http://www.independent.co.uk/ news/world/asia/india-looks-to-brain-gain-as-new-affluencedraws-migrants-back-in-their-thousands-551121.html

PricewaterhouseCoopers. (2007). Bangalore: Citizen perceptions on Democratic Capital.

Basant, R. (2006). Bangalore cluster: Evolution, growth and challenges. Ahmedabad: IIM. 
BEL. (2015, September 25). Retrieved from BELIndia: http://www.bel-india.com/

BEML. (2015, September 25). Retrieved from BEMLIndia: http://www.bemlindia.com/

BHEL. (2015, September 25). Retrieved from BHEL: http://www.bhel.com/

Census of India. (2015, July 25). Census of India. Retrieved from Census of India: http:/ / www.censusindia.gov.in/

Census of India. (2015, June 14). Migration tables 2001. Retrieved from www.censusindia.gov.in: http://censusindia.gov.in/ Tables_Published/D-Series/D-Series_link/D2_India.pdf

Chacko, E. (2007). From brain drain to brain gain: Reverse migration to Bangalore and Hyderabad, India's globalizing high tech cities. Geo Journal, 131-140.

CMTI. (2015, September 25). Retrieved from CMTI India: http://cmti-india.net/

Department of IT, BT and S E T , Goverment of Karnataka. (2011, February 2). Retrieved March 24, 2011, from http://www.bangaloreitbt.in/index.html

Department of IT, BT and S \& T. (2015, December 27). Retrieved from Department of IT, BT and S \& T: http:// www.bangaloreitbt.in

DNA. (2011, November 2). The origin and evolution of India's Silicon Valley. Bangalore.

Gowda, C. (2010, July 17). 'Advance Mysore!': The cultural logic of a developmental state. Economic and Political Weekly, 88-95.

HAL. (2015, September 25). Retrieved from HALIndia: http://www.hal-india.com

Hassan, M. (2008, April 14). India: From Brain Drain to Brain Gain. Retrieved March 24, 2011, from South Asia Biz: http://www.southasiabiz.com/2008/04/india_from_brain _drain_to_brai.html 
Heitzman, J. (1999). Corporate strategy and planning in the Science City: Bangalore as 'Silicon Valley'. Economic and Political Weekly, Vol. 34 (No. 5 ), PE2-PE11.

Heitzman, J. (2001). Becoming Silicon Valley. Seminar (Web Edition).

Heitzman, J. (2003). Geographic information systems in India's 'Silicon Valley': The impact of technology on planning Bangalore. Contemporary South Asia, 12(1), 57-83.

HMT. (2015, September 25). Retrieved from HMTIndia: http://www.hmtindia.com/

IIIT-B. (2015, December 27). Retrieved from International Institute of Information Technology-Bangalore: http:// www. iiitb.ac.in/

IISC. (2015, September 25). Retrieved from Indian Institute of Science: http:/ / www.iisc.ernet.in/

ILO-ARTEP. (1989). Employment and structural change in Indian industries: A Trade Union view-point. India: ILO.

India IT-BPM Overview. (2016, January 30). Retrieved from NASSCOM:http://www.nasscom.in/indian-itbpo-industry

ISRO. (2015, September 25). Retrieved from Indian Space Research Organization: http:/ / www.isro.gov.in/

ITI Limited. (2016, January 29). Retrieved from ITI Limited: http://www.itiltd-india.com/index

Karnataka State Electronics Development Corporation Limited. (2015, December 27). Retrieved from KEONICS: http:// www.keonics.in/

Kelly, Feenan\& McAuley. (2016). City Momentum Index 2016. Chicago: JLL.

Khadria, B. (2004). Human Resources in science and technology in India and the international mobility of highly skilled Indians. OECD Publishing: OECD Science, Technology and Industry Working Papers. 
Mascarenhas, R. C. (2012). India's Silicon Plateau: Development of Information and Communication Technology in Bangalore. India: Orient Blackswan Private Limited.

Nair, J. (2005). The Promise of the Metropolis: Bangalore's Twentieth Century. New Delhi: OUP.

NAL. (2015, September 25). Retrieved from National Aerospace Laboratories: http://www.nal.res.in/

NRIF. (2009). Pilot Study on India's Reverse Brain Gain (RBG) in Liberalized Era. Natural Resources India Foundation.

Pai, Mohandas. (2012). KIG 2020. Bangalore: Karnataka Information Communication Technology Group.

Parthasarathy, B. (2004, September). India's Silicon Valley or Silicon Valley's India? Socially embedding the Computer Software Industry in Bangalore. International Journal of Urban and Regional Research, 28(3), 664-685.

Patni, A. (1999). Silicon Valley of the East: Bangalore's Boom. Harvard International Review, 8-9.

Rai, S. (2009, March 17). Bangalore's Brain Gain: When Tech Entrepreneurs Return Home. Retrieved March 24, 2011, from Silicon.com: http://www.silicon.com/management/cioinsights/2009/03/17/ bangalores-brain-gain-39407417/

Saxenian, A. (2000). Bangalore: The Silicon Valley of Asia? Stanford University: Center for Research on Economic Development and Policy Reform .

Stremlau, J. (1996, November). Bangalore: India's silicon city. Monthly Labour Review, 50-51.

Texas Instruments: Company info. (2016, January 30). Retrieved from Texas Instruments: http://www.ti.com/lsds/in/company_info.page

The Hindu. (2010, September 28). Bangalore: The success story of ICT industry. Bangalore.

Venkat, A. (2015, February 16). Bengaluru is India's start up capital. Retrieved from Bangalore Mirror: http:// 
www.bangaloremirror.com/bangalore/others/Bengaluruis-Indias-start-up-capital/articleshow / 46256286.cms

Viswanathan, N. (1998). Proceedings of the Government of Karnataka. Bangalore: Karnataka Gazette.

Vyasulu, V. (1989). Nehru and the Visvesvaraya Legacy. Economic and Political Weekly, 1700-1704.

Wijesinha, R. T. (2009, October 4). Transition from 'Brain Drain' to 'Brain Gain'. Retrieved March 24, 2011, from The Sunday Times: http://sundaytimes.lk/ 091004/ FinancialTimes/ ft26.html 